\title{
Analisis Timbal pada Air, Sedimen dan Enhalus Acoroides, Royle 1839 (Angiosperms: Hydrocharitaceae) di Perairan Jepara
}

\author{
Zhulian Hikmah Hasibuan, Bambang Yulianto dan Ria Azizah \\ Departemen IImu Kelautan, Fakultas Perikanan dan IImu Kelautan, Universitas Diponegoro \\ JI. Prof. H. Soedarto S.H, Tembalang, Semarang, Jawa Tengah 50275 Indonesia \\ ${ }^{\star}$ Corresponding author, e-mail : zhulianhikmah@gmail.com
}

\begin{abstract}
ABSTRAK: Pantai Bandengan dan Pulau Panjang merupakan salah satu tempat obyek wisata yang berada di Jepara. Aktivitas perkapalan merupakan salah satu sumber penyebab masuknya bahan pencemar logam berat kedalam perairan. Tujuan penelitian ini adalah mengetahui kandungan logam berat $\mathrm{Pb}$ (Timbal) pada air, sedimen dan lamun Enhalus acoroides (akar, batang dan daun), dan mengetahui kemampuan Enhalus acoroides dalam mengakumulasi dan Translokasi logam berat $\mathrm{Pb}$ di perairan Pantai Bandengan dan Pulau Panjang, Jepara. Penelitian ini menggunakan metode deskriptif analitik, sedangkan metode penentuan lokasi menggunakan metode purposive sampling. Materi yang digunakan dalam penelitian ini adalah sampel, air, sedimen dan akar, batang, daun lamun Enhalus acoroides. Penelitian dilaksanakan pada bulan Oktober-November 2019. Analisis sampel dilakukan di Laboratorium Kimia Analitik Fakultas Matematika dan IImu Pengetahuan Alam, Universitas Gadjah Mada. Hasil penelitian menunjukan nilai akumulasi logam berat $\mathrm{Pb}$ (Timbal) pada akar Enhalus acoroides di Pantai Bandengan berkisar antara 1,83 - 2,16 mg/l dan pada Daun berkisar antara 1,50 - 2,16 mg/l, sedangkan akumulasi logam berat pada $\mathrm{Pb}$ (Timbal) pada akar Enhalus acoroides di Pulau Panjang berkisar antara 1,66 - 2,82 mg/l dan pada daun 1,33 - 2,98 mg/l. Kemampuan lamun Enhalus acoroides yang ada di Pantai Bandengan dan Pulau Panjang dalam mengakumulasi logam berat $\mathrm{Pb}$ (Timbal) termasuk dalam kategori rendah dengan nilai faktor biokonsentrasi rata-rata $<250$.
\end{abstract}

Kata kunci: Enhalus acoroides, Pb (Timbal), Pantai Bandengan, Pulau Panjang, Biokonsentrasi.

\section{Analysis of Heavy Metal Lead in Water, Sediment, Enhalus Acorides Royle 1839 (Angiosperms: Hydrocharitaceae) in Jepara}

\begin{abstract}
Bandengan Beach and Panjang Island are one of a tourist destinations in Jepara. The activities of shipping are ones caused of heavy metal pollutions into the waters. Seagrass is flowering water plants and the ability to adapt to live and grow in the marine environment. Enhalus acoroides is a type of seagrass that grows around Bandengan Beach and Panjang Island. The presence of seagrass in the sea can be a bioindicator of heavy metal pollution because to absorbs accumulate contaminants.. The pupose of this research ware to know and compare the content of heavy metals $\mathrm{Pb}$ (Lead) in Waters, Sediment, and roots, stems, leaf in Enhalus acoroides Seagrass in Bandengan Beach and Panjang Island. This research used descriptive method, while the method of determining the location used purposive sampling method. The material used in this research are the samples of Waters, Sediment, and roots, stems, leaf in Enhalus acoroides Seagrass. The research was carried out in Oktober-November 2019. The analysis of samplescarried out in the laboratory of analytical chemistry, Faculty of Math and Science, Gajah Mada University. The results showed the value of the accumulations of heavy metal $\mathrm{Pb}$ (Lead) from the root Enhalus acoroides in Bandengan Beach ranging between 1,83-2,16 mg/l and 1,50 $-2,16 \mathrm{mg} / \mathrm{l}$ from the leaves, while the acvumulations of heavy metals $\mathrm{Pb}$ (Lead) from the root Enhalus acoroides in Panjang Island range between 1,66 - 2,82 mg/l and 1,33 - 2,98 mg/l from the leaves. The ability Enhalus acoroides in Bandengan Beach and Panjang Island to accumulate the heavy metals $\mathrm{Pb}$ (Lead) can be concluded under low category because of bioconcentrate factor value $<250$
\end{abstract}

Keywords: Macrozoobentos, Seagrass, Telaga Waters, Bengkoang Island 


\section{PENDAHULUAN}

Seiring berkembang pesatnya kemajuan zaman serta meningkatnya jumlah penduduk baik perkotaan maupun daerah didaerah pesisir, ternyata mengakibatkan sumberdaya laut menjadi terbatas. Menurut Ketaren et al., 2019, meningkatnya jumlah penduduk maka aktivitas penduduk juga bertambah mulai dari petanian, perindustrian, hal itu yang memicu pembuangan limbah semangkin meningkat. Akibatnya kualitas perairan laut menjadi turun dan menjadi tercemar. Masuknya kotoran, limbah dan hasil buangan aktivitas manusia ke perairan disebut pencemran laut.

Menurut Wahyuningsih (2015) Sedangkan tanah yang berpasir lebih rendah kemampuannya untuk mengikat logam berat.Pantai Bandengan daerah yang berhubungan erat dengan kondisi fisik dan kimiawi daratan dan lautan, berbagai aktivitasnya seperti aktivitas transportasi laut, dan limbah atau sampah rumah tangga yang menuju ke laut. Banyaknya wisatawan yang berkunjung sehingga membuat banyak aktivitas kapal berlalu lalang dari dan menuju Pulau Panjang yang diduga menjadi sumber pencemaran logam berat $\mathrm{Pb}$ (Nindya puspa dan Achmad, 2017).

Tumbuhan Lamun (seagrass) merupakan tanaman tinggi yang memiliki akar batang daun yang biasanya ditemui dalam keaadan terbenam di dalam air. Rhizome adalah bagian dari lamun yang bentuknya dikenal dengan berbuku buku ydan pastinya selalu berada pada air (Wulandari, Riniatsih \& Yudiati, 2013). Penelitian ini bertujuan untuk mengetahui kandungan logam berat $\mathrm{Pb}$ (Timbal) pada air, sedimen dan lamun Enhalus acoroides (akar, batang dan daun), dan mengetahui kemampuan Enhalus acoroides dalam mengakumulasi dan melakukan Translokasi logam berat $\mathrm{Pb}$ di perairan Pantai Bandengan dan Pulau Panjang, Jepara.

\section{MATERI DAN METODE}

Pada penelitian ini materi yang digunakan adalah air, sedimen dan akar batang daun lamun jenis Enhalus acoroides diambil di perairan Pantai Bandengan dan Pulau Panjang. Pantai Bandengan dan Pulau Panjang sering dijumpa jenis lamun Enhalus acoroides dan Thalassia hemprichii, berbeda dengan Cymodocea sp dan Syringodium yang hanya dijumpai di Pulau Panjang. Lamun yang dapat hidup diberbagai substrat serta memiliki bentuk paling besar dan helaian daun nya dapat mencapai lebih dari 1 meter yaitu Enhalus acoroides (Riniatsih, 2016).

Metode yang digunakan dalam penelitian ini adalah metode deskriptif analitik, yaitu suatu metode dalam penelitian yang bertujuan menggambarkan penggunaan berbagai data historis untuk menggambar perbandingan. Penentuan lokasi penelitian dilakukan berdasarkan hasil observasi awal dengan memperhatikan keterwakilan dari lokasi penelitian secara keseluruhan pada sumber pencemaran dan luas sebaran lamun di perairan Pantai Bandengan dan Pulau Panjang, Jepara. Metode yang digunakan untuk menentukan stasiun penelitian adalah purposive sampling method yaitu teknik penentuan stasiun sampling dengan pertimbangan tertentu (Bonauli, Helmi \& Pranowo, 2016).

Faktor biokonsentrasi dihitung untuk mengetahui kemampuan lamun Thalassia hemprichii dalam mengakumulasi logam berat Timbal $(\mathrm{Pb})$ pada air dan sedimen melalui tingkat biokeonsentrasi faktor (BCF). Analisisa TF (Translocation Factor) digunakan untuk menghitung proses translokasi logam berat $\mathrm{Pb}$ dari akar ke daun. Fitoremediasi (FTD) merupakan selisih antara nilai BCF Lamun-Sedimen dengan TF. Nilai FTD diperoleh dengan mengurangi nilai BCF dengan nilai TF. Data yang sudah didapatkan kemudian dianalisis dengan deskriptif dan patokannya adalah baku mutu lingkungan yang sudah ditentukan. Baku mutu pada timbal $(\mathrm{Pb})$ dalam lumpur atau sedimen di Indonesia belum ditetapkan, dan sementara acuannya adalah baku mutu berdasarkan IADC/CEDA(1997).

\section{HASIL DAN PEMBAHASAN}

Hasil yang diperoleh menunjukkan bahwa kandungan $\mathrm{Pb}$ pada air di Pulau Panjang lebih tinggi dibandingkan di Pantai Bandengan, hal ini disebabkan karena Pulau Panjang merupakan tempat wisata yang banyak dikunjungi wisatawan, dan tak hanya itu saja aktivitas kapal yang berlalu lalang juga dapat mempengaruhi pencemaran. Berbagai kegiatan wisatawan yang 
menyebabkan pencemaran juga. mempengaruhi terhadap kualitas air dan berpengaruh terhadap kelarutan logam berat di perairan (Rizkiana dan Karina, 2017).

Analisis logam $\mathrm{Pb}$ pada sedimen di Pantai Bandengan menunjukkan hasil yang tidak begiti jauh selisihnya yang mana pada Stasiun I dan II memiliki nilai yang tidak begitu jauh berbeda sedangkan pada Stasiun III memiliki nilai yang rendah. Hal ini diduga karena letak Stasiun III yang cukup jauh dari sumber pencemar. Tingginya kandungan $\mathrm{Pb}$ pada Stasiun I dan II juga disebabkan karena bentuk sedimen pada stasiun tersebut merupakan pasir halus. Indirawati (2017) mengatakan bahwa secara umum semangkin kecil ukuran butir, maka semangkin besar kandungan logam beratnya. Hal ini disebabkan karena ukuran partikel sedimen yang halus memiliki permukaan yang besar sehingga mampu mengikat $\mathrm{Pb}$ lebih banyak dari pada ukuran partikel sedimen yang lebih besar

Tabel 1. Rata - rata Kandungan Logam Berat $\mathrm{Pb}$ (Timbal) pada Sampel Air, Sedimen, dan Lamun Enhalus acoroides di lokasi penelitian.

\begin{tabular}{|c|c|c|c|c|c|}
\hline Kelompok & Air (mg/l) & $\begin{array}{l}\text { Sedimen } \\
(\mathrm{mg} / \mathrm{kg})^{\star}\end{array}$ & Akar $(\mathrm{mg} / \mathrm{kg})^{*}$ & Daun $(\mathrm{mg} / \mathrm{kg})^{*}$ & $\begin{array}{l}\text { Batang } \\
(\mathrm{mg} / \mathrm{kg})^{*}\end{array}$ \\
\hline PB I & $0,054 \pm 0,012$ & $8,612 \pm 1,513$ & $1,995 \pm 0,572$ & $1,830 \pm 0,286$ & $3,410 \pm 0,248$ \\
\hline PB II & $0,034 \pm 0,031$ & $8,942 \pm 0,568$ & $2,161 \pm 0,286$ & $1,995 \pm 0,757$ & $3,230 \pm 0,383$ \\
\hline PB III & $0,047 \pm 0,020$ & $7,951 \pm 1,511$ & $1,995 \pm 0,572$ & $1,500 \pm 0,286$ & $3,410 \pm 0,248$ \\
\hline Rata rata & 0,045 & 8,501 & 2,050 & 1,775 & 3,350 \\
\hline PP I & $0,047 \pm 0,000$ & $7,945 \pm 0,570$ & $2,357 \pm 0,262$ & $2,161 \pm 0,859$ & $0,344 \pm 0,286$ \\
\hline PP II & $0,047 \pm 0,020$ & $8,935 \pm 0,570$ & $2,185 \pm 0,837$ & $1,996 \pm 0,757$ & $0,344 \pm 0,286$ \\
\hline PP III & $0,054 \pm 0,023$ & $8,275 \pm 0,990$ & $1,854 \pm 0,750$ & $2,327 \pm 1,032$ & $0,509 \pm 0,286$ \\
\hline Rata rata & 0,049 & 8,385 & 2,132 & 2,161 & 0,399 \\
\hline Baku Mutu & $0,008 \mathrm{ppm} *$ & $36 \mathrm{mg} / \mathrm{kg}^{\mathrm{b})}$ & $0,5 \mathrm{~m}$ & & \\
\hline
\end{tabular}

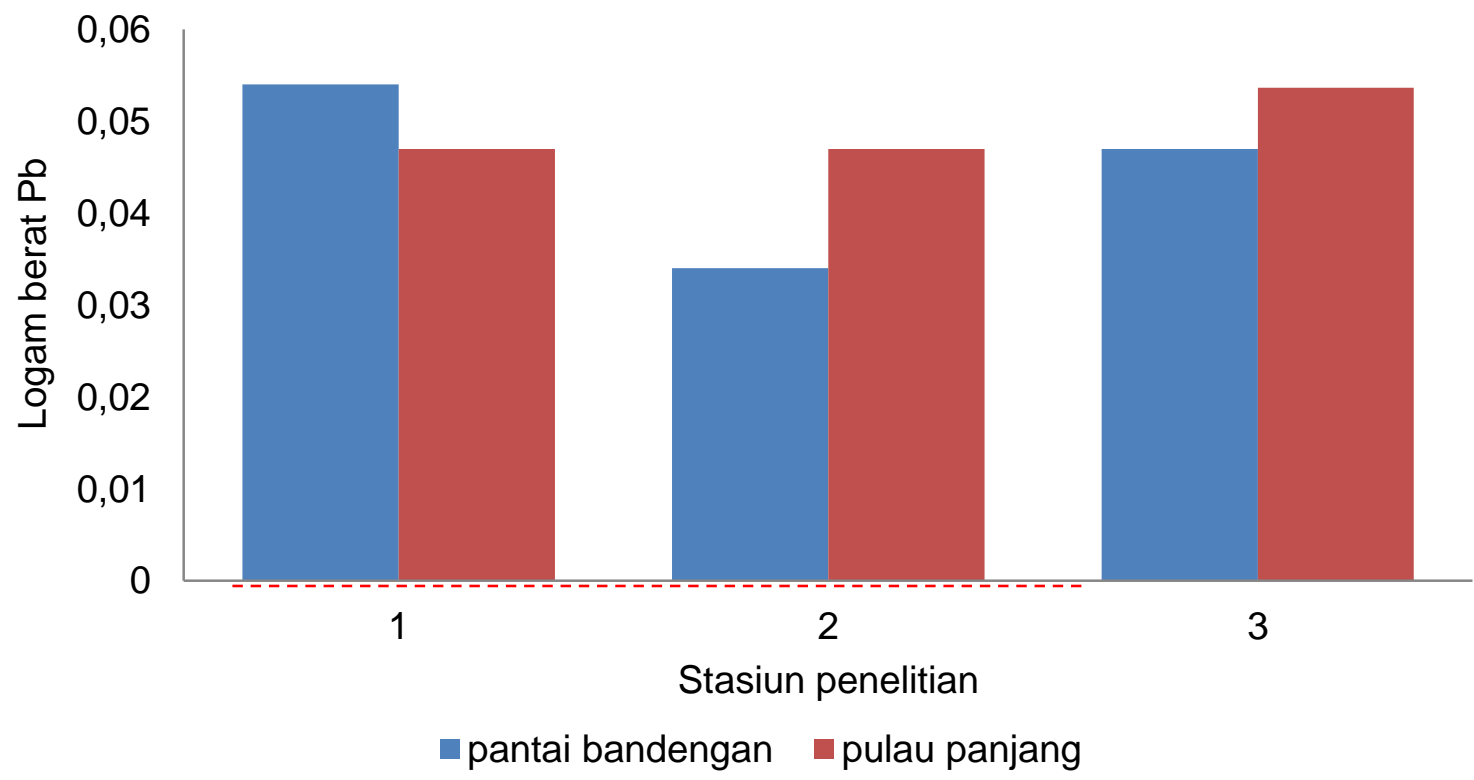

Gambar 1. Kandungan Logam Berat Timbal $(\mathrm{Pb})$ pada air 


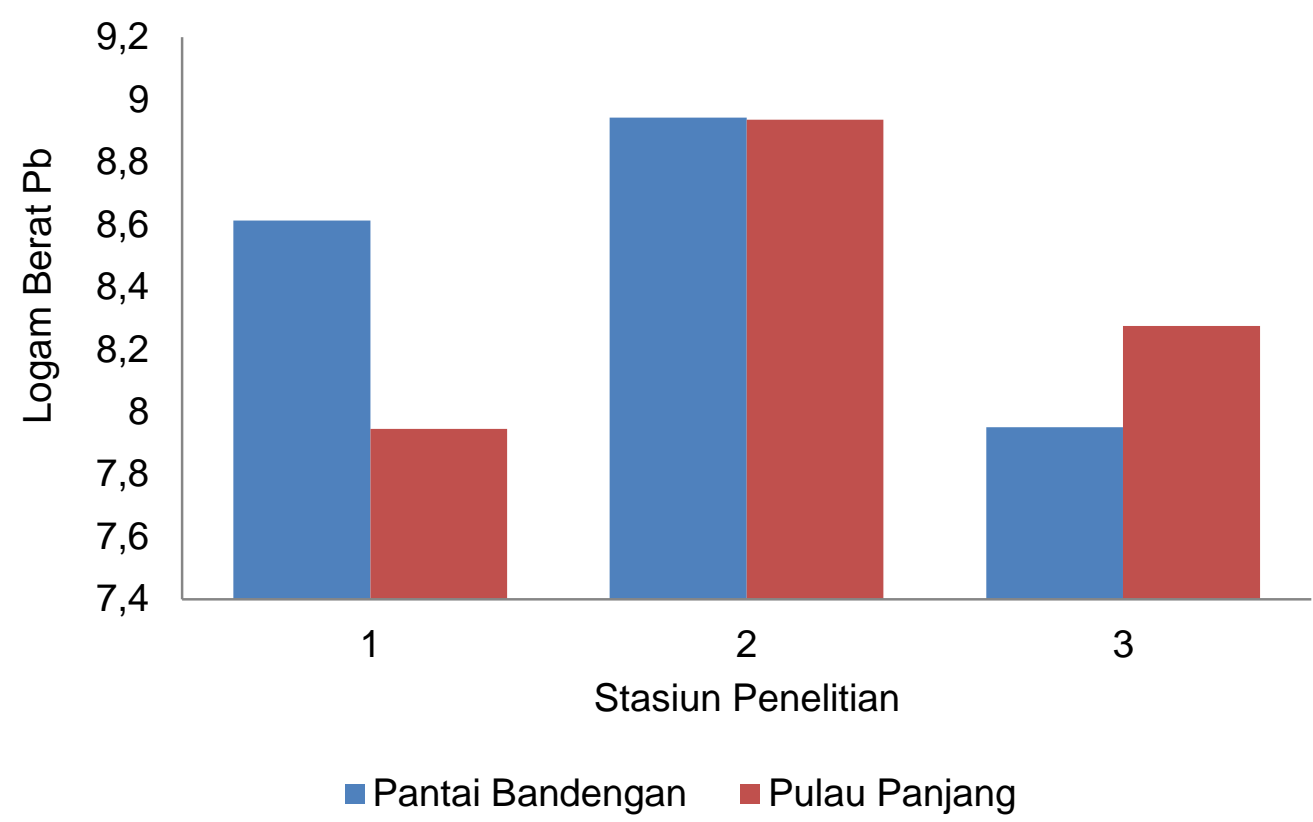

Gambar 2. Kandungan Berat Logam Timbal (Pb) pada sedimen

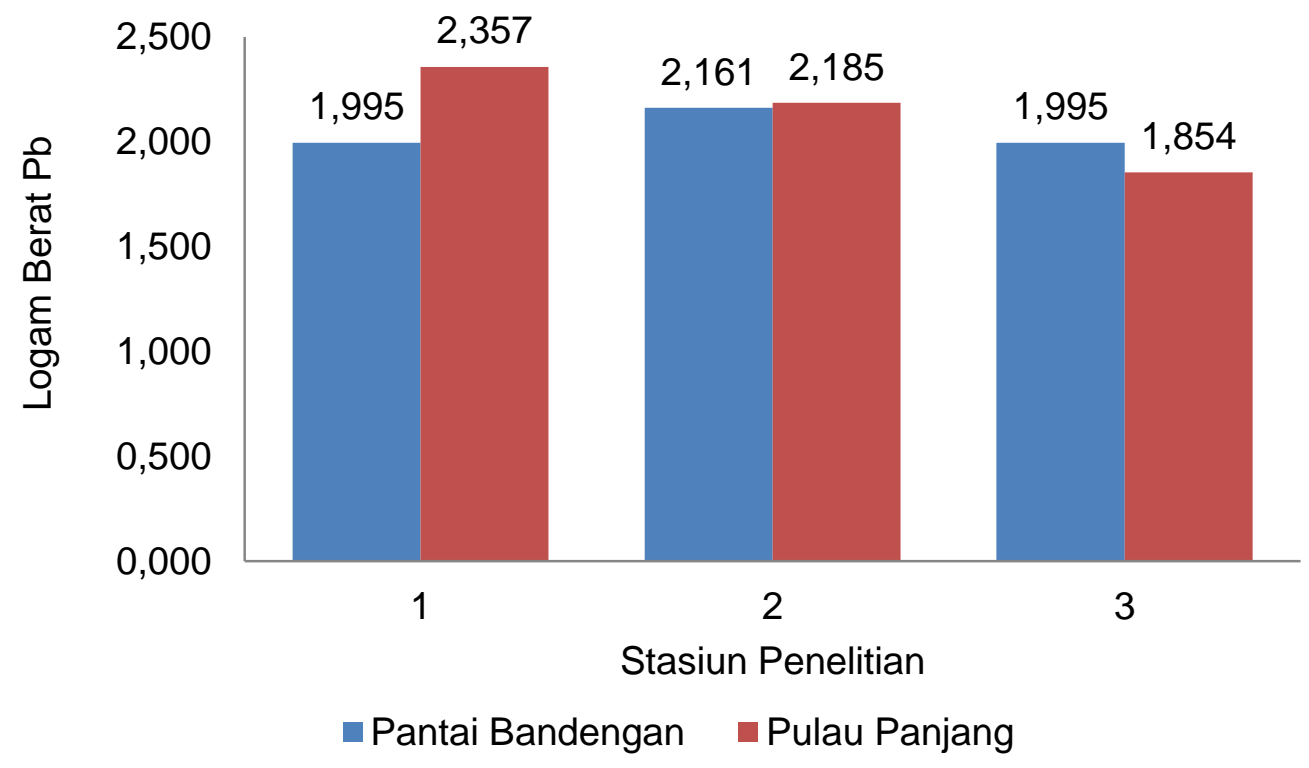

Gambar 3. Kandungan Berat Logam Timbal $(\mathrm{Pb})$ pada akar Lamun Enhalus acoroides

Berdasarkan hasil analisa kandungan logam berat $\mathrm{Pb}$ pada akar lamun Enhalus acoroides di Pantai Bandengan menunjukan hasil yang rendah yang mana konsentrasi yang tertinggi berada pada stasiun II dan terendah pada stasiun III. Tingginya konsentrasi logam Pb Pada akar lamun di stasiun II diduga karena umur lamun yang cukup tua dilihat dari kondisi fisik berupa daun yang tebal dan berwarna hijau pekat. (Azizah et al., 2018).

Menurut Damaianto et al., 2014, semakin bertambah umur tanaman maka penyerapan juga akan meningkat samapai pada waktu tertentu akan mencapai maksimum dan akan turun kembali. Tingginya serapan unsure hara yang diserap oleh akar akan ditransportasikan melalui aringan pengangkut (xylem dan floem) menuju ke semua bagian tumbuhan. Logam berat yang diakumulasikan lama kelaman akan bertambah sesuai dengan umur lamun dikarenakan semangkin tua lamun maka kemampuan daun menyerap logam berat meningkat. Hal ini sejalan dengan keberadaan pectin yang ada pada daun lamun, dan anatomi yang khas dari daun lamun 


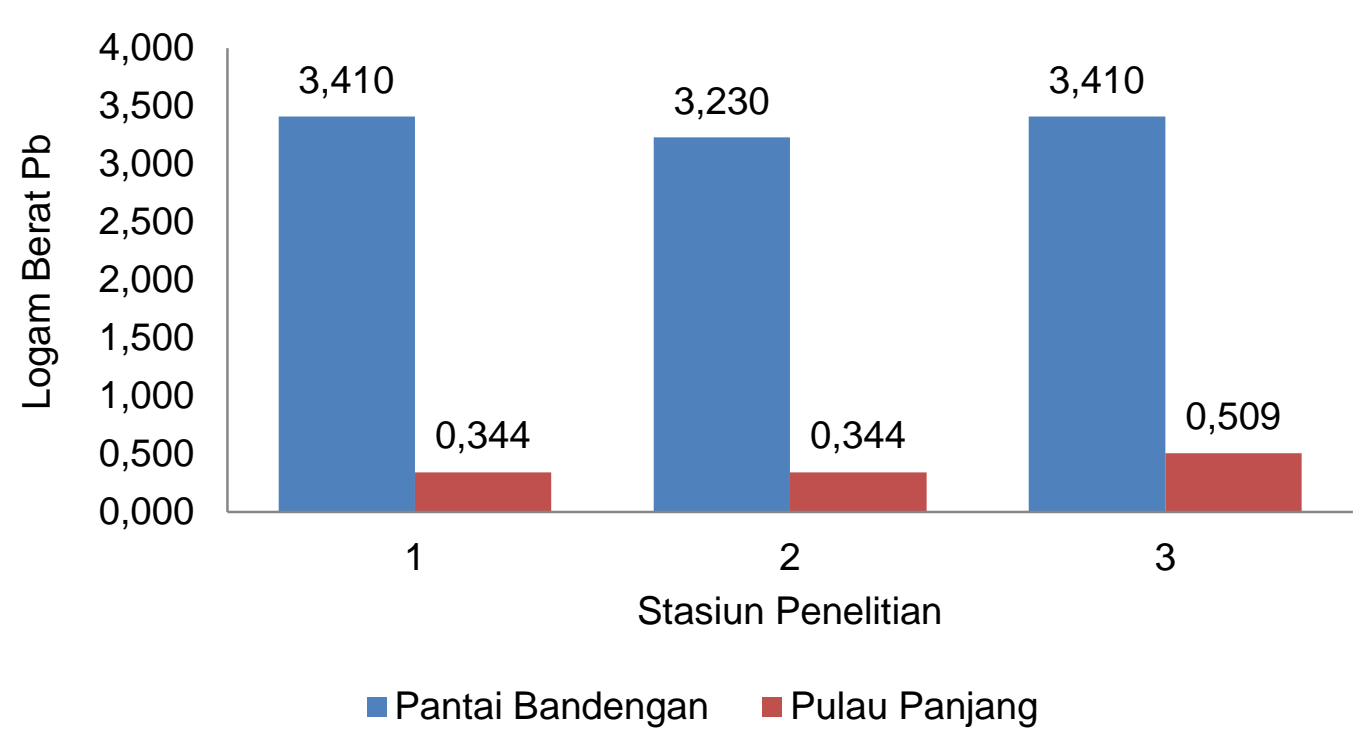

Gambar 4. Kandungan Berat Logam Timbal $(\mathrm{Pb})$ pada batang Lamun Enhalus acoroides

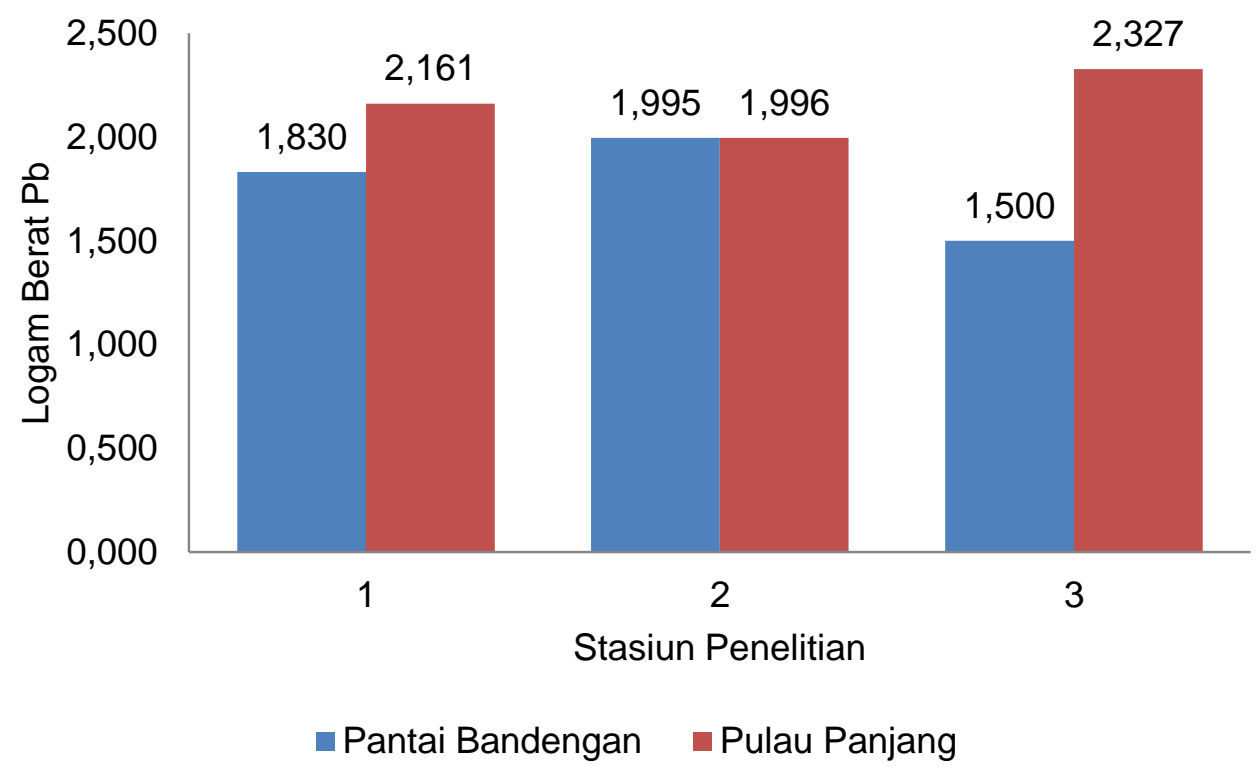

Gambar 5. Kandungan Berat Logam Timbal (Pb) pada daun Lamun Enhalus acoroides

adalah ketidakadaan stomata dan keberadaan kutikel yang tipis. Kutikel daun yang tipis tidak dapat menahan pergerakan ion dan difusi karbon sehingga daun dapat menyerap nutrient langsung dari air laut, sehingga logam berat yang dapat secara cepat diserap oleh daun lamun (Syahminan et al, 2015).

Faktor Biokonsentrasi (BCF) akar dihitung dangan perbandingan antara kandungan logam berat $\mathrm{Pb}$ di akar dengan kandungan logam berat $\mathrm{Pb}$ di sedimen, sedangakan $\mathrm{BCF}$ daun dihitung dengan perbandingan kandungan logam $\mathrm{Pb}$ pada daun dan kandungan logam $\mathrm{Pb}$ pada sedimen. Nilai BCF tertinggi di Pantai Bandengan terdapat pada batang di stasiun I sedangkan di Pulau Panjang terdapat pada daun di stasiun I. Hasil perhitungan BCF di lokasi penelitian membuktikan bahwa lamun Enhalus acoroides mampu untuk menyerap dan mengakumulasi logam berat yang terdapat di lokasi penelitian. Nilai biokonsentrasi lamun Enhalus acoroides pada semua stasiun di Pantai Bandengan dan Pulau Panjang berada dibawah $<250$. Nilai Faktor Translokasi (TF) dilakukan untuk mengetahui kemampuan tanaman untuk mentranslokasi logam dari akar ke 
seluruh bagian tumbuhan. Hasil perhitungan nilai faktor translokasi tertinggi pada stasiun I di Pulau Panjang dan terendah pada stasiun II di Pulau Panjang. Perbedaan kemampuan translokasi ini disebabkan karena adanya perbedaan umur lamun yang berpengaruh terhadap daya serap daunnya (Desriyan \& Kancitra, 2015).

Nilai fitoremediasi pada lamun Enhalus acorides disetiap stasiun Pantai Bandengan dan Pulau Panjang memiliki nilai yang berbeda. Nilai fitoremediasi tertinggi di Pantai Bandengan adalah di Stasiun II dan di Pulau Panjang di Stasiun III. Nilai Fitoremediasi yang dihasilkan beragam, nilai fotoremediasi negatif menunjukkan bahwa faktor translokasi (TF) dari akar menuju daun yang dihasilkan dari lamun Enhalus acoroides tinggi, sedangkan nilai fitoremediasi positif menunjukkan bahwa kemampuan lamun Enhalus acoroides dalam mengakumulasi logam $\mathrm{Pb}$ melalui faktor biokonsentrasi (BCF) tinggi. Hasil tersebut dapat disimpulkan bahwa lamun Enhalus acoroides dapat digunakan untuk tujuan fitoremediasi.

\section{KESIMPULAN}

Berdasarkan hasil penelitian dapat disimpulkan bahwa kandungan logam berat $\mathrm{Pb}$ pada kolom air di Pantai Bandengan dan Pulau Panjang melebihi baku mutu. Sedangkan logam berat $\mathrm{Pb}$ pada sedimen belum melebihi nilai baku mutu dan lamun Enhalus acoroides sudah melebihi nilai baku mutu yang mana berarti termasuk tercemar sedang.

\section{UCAPAN TERIMAKASIH}

Artikel ini merupakan bagian dari penelitian yang berjudul "Analisis Kandungan Logam Berat Timbal pada Air, Sedimen dan Enhalus Acoroides di Perairan Jepara" untuk memperoleh gelar Sarjana Strata Satu pada Departemen IImu Kelautan, Fakultas Perikanan dan IImu Kelautan, Universitas Diponegoro, Semarang.

\section{DAFTAR PUSTAKA}

Azizah, R. Malau, R., Susanto, A.B., Santosa, G.W., \& Hartati, R. 2018. Kandungan Logam Berat Timbal ( Pb ) Pada Air, Sedimen, Dan Rumput Laut Sargassum sp. Jurnal Kelautan Tropis, 23:155-166. DOI: 10.14710/jkt.v21i2.3010.

Bonauli, M., Helmi, M., \& Pranowo, W.S. 2016. Analisis Karakteristik Arus Harmonikakibat Pasang Surut Di Perairan Teluk Awur Kabupaten Jepara. Journal of Oceanography, 5(1):1-10.

Damaianto, B.B., \& Masduqi, A.A. 2014. Indeks pencemaran air laut pantai utara Kabupaten Tuban dengan parameter logam. Jurnal Teknik ITS, 3(1):D1-D4. DOI: 10.12962/j23373539. v3i1.5378

Desriyan, R. Eka, R. \& Kancitra, P. 2015. Identifikasi Pencemaran Logam Berat Timbal (Pb) pada Perairan Sungai Citarum Hulu Segmen Dayeuhkolot sampai Nanjung. Reka Lingkungan, 3(1):260-271

Indirawati, S.M. 2017. Pencemaran Logam Berat $\mathrm{Pb}$ dan $\mathrm{Cd}$ dan Keluhan Kesehatan pada Masyarakat di Kawasan Pesisir Belawan. Jurnal Ilmiah Penelitian Kesehatan, 2(2):54-60. DOI: 10.30829/jumantik.v2i2.1165

Ketaren, C.B.B., Hakim, A.A., Fahrudin, A., \& Wardiyatno, Y. 2019. Kandungan Logam Berat Pb Undur-Undur Laut dan Implikasinya Pada Kesehatan Manusia. Jurnal Biologi Tropis, 19(1): 90-100. DOI: 10.29303/jbt.v19i1.1066

Nindyapuspa, A. Achmad, C, N. 2017. Distribusi Logam Berat Timbal di Perairan Laut Kawasan Pesisir Gresik. AL-ARD : Jurnal Teknik Lingkungan. 1:1-5.

Riniatsih, I. 2016. Distribusi Jenis Lamun Dihubungkan dengan Sebaran Nutrien Perairan di Padang Lamun Teluk Awur Jepara. Jurnal Kelautan Tropis. 2:101-107. DOI: 10.14710/jkt.v19i2.824

Rizkiana, L. Karina, S. Studi, P. Kelautan, I., Syiah, U. Studi, P. \& Perairan, B. 2017. Analisis Timbal ( $\mathrm{Pb}$ ) Pada Sedimen dan Air Laut di Kawasan Pelabuhan Nelayan Gampong Deah Glumpang Kota Banda Aceh. Jurnal IImiah Mahasiswa Kelautan dan Perikanan Unsyiah, 2:89-96. 
Syahminan, S., Riani, E., Anwar, S., \& Rifardi, R. 2015. Telaahan Logam Berat Pb Dan Cd Pada Sedimen Di Perairan Barat Laut Dumai-Riau. Jurnal Pengelolaan Sumberdaya Alam dan Lingkungan (Journal of Natural Resources and Environmental Management), 5(2):133-140. DOI : $10.29244 /$ jpsl.5.2.133

Wahyuningsih, T. 2015. Pencemaran $\mathrm{Pb}$ dan Cd pada Hasil Perikanan Laut Tangkapan Nelayan di Sekitar Teluk Jakarta. Prosiding KPSDA, 1(1):105-111

Wulandari, D., Riniatsih, I., \& Yudiati, E. 2013. Transplantasi Lamun Thalassia hemprichii dengan Metode Jangkar di Perairan Teluk Awur dan Bandengan, Jepara. Journal of Marine Research, 2(2), 30-38.DOI : 10.14710/jmr.v2i2.2347 